\title{
Co je nového ve světě sportovní výživy
}

\section{The world of sports nutrition - the new insights}

\author{
Michal Kumstát \\ Fakulta sportovních studií Masarykovy univerzity, Brno, Česko
}

\begin{abstract}
Abstrakt
Sportovní výživa je progresivně se rozvijející vědní obor. Výživové strategie sportovce zaměřené na zabezpečeni energetických substrátů a dalších ergogenních prostředků podporujících dostupnost energie, oddalujících rozvoj únavy anebo zvyšujících závodní výkon jsou založeny na rozsáhlé literaturou podpořené evidenci. Cílem práce je identifikovat novinky v doporučeních sportovní výživy uveřejněné $v$ konsenzuálních vyjádřeních Americkou společností sportovní medicíny (ACSM) a Mezinárodním olympijským výborem (IOC) po r. 2010. Kontrolními texty byla souhrnná sdělení publikovaná ACSM a IOC pred r. 2010. Energetická dostupnost (ED), relativní energetická nedostatečnost ve sportu (RED-S), ergogenní role prijímaných sacharidů (S) v průběhu zatížení (kontakt S s ústy u 45-60min zatižení, $t z v$. "mouth rinse" a revize doporučeného množství S během výkonu $>2,5 \mathrm{~h}-90 \mathrm{~g} \mathrm{~S} / \mathrm{h}$ ) a koncept "train-low, compete-high" manipulující sacharidovou dostupnosti jsou identifikované klíčové oblasti, které tvoři základ současných inovovaných doporučení.
\end{abstract}

\begin{abstract}
Sport nutrition is progressively increasing scientific discipline being an important part of the field of sports medicine. Competition and training nutrition strategies that focus on sufficient macronutrient intake and ergogenic aids to promote energy availability and delay determinants of fatigue are currently based on sound scientific evidence. The aim of the review is to analyze the guidelines for exercise and sport nutrition published by the American College of Sport Nutrition (ACSM) and the International Olympic Committee (IOC) in the period before and after 2010. Energy availability (EA), relative energy deficiency in sport (RED-S), carbohydrate feeding during exercise (such as a mouth rinse and multitransportable carbohydrate feeding during long term exercise) and eventually "trainlow, compete high" nutrition strategy intentionally manipulating with carbohydrate availability have been identified as novel and innovative. Sport nutrition recommendations issued by well-respected scientific authorities are currently revised according to the above mentioned topics and are now well accepted even by athletes.
\end{abstract}

\section{Klíčová slova}

Sacharidová dostupnost; energetická dostupnost; výplach úst; nutriční strategie "train-low, compete high".

\section{Key words}

Carbohydrate availability; energy availability; mouth rinse; train-low, compete-high nutrition strategy.

\section{ÚVOD}

Sportovní výživa je samostatnou vědní disciplínou. Obrovský rozmach publikačních výsledků v renomovaných odborných periodicích dokumentuje změny, které provází výzkum v oblasti sportovní výživy. Výživové strategie sportovce zaměřené na zabezpečení energetických substrátů a dalších ergogenních prostředků podporujících dostupnost energie, oddalujících rozvoj únavy a zvyšujících 
závodní výkon jsou založeny na rozsáhlé literaturou podpořené evidenci ${ }^{1}$. Výzkum v oblasti sportovní výživy začíná být nově orientován na interakce tréninku a specifických výživových postupů podporujících žádoucí adaptace.

V poslední dekádě začíná být soutěžní a tréninková výživa více chápána jako dvě samostatné entity. Např. Americká společnost sportovní medicíny (ACSM) ve svém posledním konsenzuálním vyjádření $^{2}$ z r. 2016 (Thomas, Erdman, \& Burke, 2016) zcela jednoznačně rozděluje tyto dvě oblasti, zatímco v prvním konsensuálním vyjádření z r. 2000 není rozdíl mezi soutěžní a tréninkovou výživou patrný.

Cílem práce je identifikovat témata sportovní výživy, která se objevila v aktuálních doporučeních sportovní výživy vydaných ACSM v r. 2016 a přináší něco nového. Společně s nosným konsensuálním vyjádřením ACSM byly posuzovány doplňující práce shrnující současné poznatky publikované po roce 2010 (IOC consensus statement on sports nutrition 2010, 2011; Close, Hamilton, Philp, Burke, \& Morton, 2016). Kontrolními odbornými texty pro objektivní posouzení „novosti“ tématu byla souhrnná sdělení publikovaná ACSM a Mezinárodním olympijským výborem před rokem 2010 (American College of Sports Medicine, American Dietetic Association, \& Dietitians of Canada, 2000; citace IOC consensus statement on sports nutrition 2003, 2004).

Analýzou nosných a kontrolních textů byla zvolena kritéria pro zařazení tématu do této přehledové práce: absence termínu $\mathrm{v}$ kontrolních textech, změna anebo doplnění konkrétního nutričního doporučení vyskytujícího se v kontrolních textech, definice nového termínu či nutriční strategie za účelem zvýšení výkonu.

Na základě zvolené metodiky byly vybrány 3 tematické oblasti s novými nebo inovovanými průřezovými tématy obsahující doporučení nově integrovaná do konsenzuálních vyjádření ACSM a IOC až po r. 2010 (tabulka č. 1).

Tabulka č. 1: Nová doporučení sportovní výživy uveřejněná ACSM a IOC po r. 2010 (Thomas et al., 2016; IOC consensus statement on sports nutrition 2010, 2011)

\begin{tabular}{|l|l|l|}
\hline Tematické oblast & $\begin{array}{l}\text { Identifikovaná nová prưřezová } \\
\text { témata }\end{array}$ & $\begin{array}{l}\text { Nová doporučení / nutriční } \\
\text { strategie vyplývající z prưř̌zových } \\
\text { témat }\end{array}$ \\
\hline Energetická potřeba & Energetická dostupnost (ED). & $\begin{array}{l}\text { zdravotní rizika a výkonnosti při } \\
\mathrm{ED} \leq 30 \mathrm{kcal} / \mathrm{kg} / \mathrm{FFM} ;\end{array}$ \\
\cline { 2 - 3 } & $\begin{array}{l}\text { Relativní energetická nedostatečnost } \\
\text { ve sportu (RED-S). }\end{array}$ & $\begin{array}{l}\text { „Ženská atletická triáda“ revidována } \\
\text { komplexnějším termínem - RED-S } \\
\text { zohledňuícím i mužské sportovce }\end{array}$ \\
\hline
\end{tabular}

Nejvýznamnější periodika podle 5letého impact faktoru z prvních dvou kvartilů podle Web of Science, která publikují původní práce, souborná sdělení nebo metaanalýzy z oblasti sportovní výživy: British Journal of Sports Medicine, American Journal of Sports Medicine, Sports Medicine, European Journal of Sport Science, Journal of the International Society of Sport Nutrition, Clinical Journal of Sport Medicine, Medicine and Science in Sport and Exercise, Journal of Applied Physiology, International Journal of Sport Nutrition and Exercise Metabolism, International Journal of Sport Medicine.

2 Tzv. ,position statement" 


\begin{tabular}{|c|c|c|}
\hline \multirow[t]{2}{*}{ Sacharidy (S) a výkon } & $\begin{array}{l}\text { Ergogenní role S prijíimaných } \\
\text { v průběhu zatížení - výplach úst } \\
\text { (mouth rinse). }\end{array}$ & $\begin{array}{l}\text { Ergogenní efekt mouth rinse } \\
\text { roztokem } S \text { v průběhu 45-60 min } \\
\text { (kontakt po dobu } 10 \text { s každých 5-10 } \\
\text { minut) submax. zatížení podložen } \\
\text { přesvědčivou evidencí }\end{array}$ \\
\hline & $\begin{array}{l}\text { Doplnění a revize stávajících } \\
\text { doporučení pro př́ijem S v průběhu } \\
\text { vytrvalostního zatí̌zení. }\end{array}$ & $\begin{array}{l}\text { Kombinovaný př́ijem glukózy } \\
\text { a fruktózy (2: 1) v souhrnném } \\
\text { množství 60-90 g/h exogenní } \\
\text { oxidaci S (až 1,5-1,7 g/min) } \\
\text { během intenzivního souvislého } \\
\text { vytrvalostního zatížení > 2,5 h }\end{array}$ \\
\hline Tréninková výživa & $\begin{array}{l}\text { Manipulace sacharidovou } \\
\text { dostupností (SD) - koncept train-low, } \\
\text { compete-high a strategie sleep low. }\end{array}$ & $\begin{array}{l}\text { Řízené zařazení } 2 \text { tréninkových } \\
\text { jednotek (TJ)/týden v podmínkách } \\
\text { SD (např. trénink s vyčerpanými } \\
\text { zásobami glykogenu) vede } \\
\text { k významným př́íznivým adaptačním } \\
\text { změnám }\end{array}$ \\
\hline
\end{tabular}

' Platí u výkonnostních sportovců při min. 6-8 TJ/týdně

\section{Energetická potřeba sportovce}

Energetická bilance je klasický koncept posuzující vztah mezi přijatou a vydanou energií. Energetická potřeba sportovců je nově posuzována pomocí energetické dostupnosti (ED) (energy availibility). Energetická dostupnost je celkové množství energie, které organizmu sportovce zbývá, odečteme-li tréninkový anebo závodem indukovaný energetický výdej od denního energetického př́ijmu (Loucks, Kiens, \& Wright, 2011) Výsledná ED je vyjádřena v kcal nebo kJ a je vztažena na beztukovou tělesnou hmotnost (FFM) sportovee:

ED $(\mathrm{kcal} / \mathrm{kg} F F M)=$ energetický př́jem za den (kcal) - energie vydaná na tréninkovou anebo soutěžní (závodní) pohybovou aktivitu za jeden den (kcal)/beztuková tělesná hmotnost (kg).

Energetická dostupnost je chápána jako energie, kterou organizmus disponuje k energetickému pokrytí elementárních fyziologických procesů (termoregulace, růst, reprodukce, buněčná biosyntéza, imunitní děje) a všech zbývajících habituálních netréninkových aktivit.

Změny v ED jsou nejčastěji odrazem záměrné nebo neodborné manipulace s energetickým př́ijmem (např. př́sná anebo opakovaná energetická restrikce) a energetickým výdejem (např. zvýšení tréninkového objemu), nebo kombinací obou faktorů. Mezinárodní olympijský výbor ve svých doporučeních na energetickou dostupnost upozorňuje poprvé v r. 2010 (IOC consensus statement on sports nutrition 2010, 2011).

Podle současných poznatků dlouhodobě nízká ED ( $\leq 30 \mathrm{kcal} / \mathrm{kg} / \mathrm{FFM} / \mathrm{den})$ negativně ovlivňuje krátkodobou i dlouhodobou výkonnost, potlačuje regenerační schopnosti, obranyschopnost sportovců a ovlivňuje správný vývoj a růst sportujících dětí a adolescentů. Za optimální ED se považuje hodnota $\sim 45 \mathrm{kcal} / \mathrm{kg} / \mathrm{FFM} / \mathrm{den}$ (Loucks et al., 2011).

Koncept ED byl vyvinut na základě studia tzv. ženské atletické triády. Syndrom ženské atletické triády se podle dřivejěších definic z r. 1997 a 2005 manifestoval poruchami př́jmu potravy, amenoreou a osteoporózou (Nattiv et al., 2007) V současnosti je syndrom chápán jako kombinace poruchy menstruačního cyklu, nízké kostní density (BMD) a nově je podmiňujícím faktorem právě nízká ED 
(Barrack, Ackerman, \& Gibbs, 2013) Ackerman, \& Gibbs, 2013. Definice atletické triády (interrelace 3 faktorů) ignoruje mnohem komplexnější dopady nízké ED na organismus sportovce. Ukazuje se, že mužští sportovci nejsou vůči dopadům snížené ED imunní, a proto IOC ve svém recentním konsenzuálním vyjádření navrhuje revidovat termín atletické triády a přichází s novým konceptem, tzv. relativní energetickou nedostatečností ve sportu (RED-S; v angl. relative energy deficiency in sport; Mountjoy et al., 2014).

Relativní energetickou nedostatečností ve sportu jsou komplexně vyjádřeny negativní fyziologické dopady a komplikace pozorované u mužských a ženských sportovců, jejichž energetický př́jem nedostatečně pokrývá funkční potřeby organizmu poté, co je odečten tréninkový energetický výdej. Příkladem zdravotních dopadů vyplývajících z RED-S jsou menstruační, endokrinní, metabolické, hematologické, psychologické, kardiovaskulární, gastrointestinální a imunologické dysfunkce. Z pohledu výkonu a tréninkové adaptace je snížena vytrvalostní kapacita, zvýšené riziko zranění, snížená tréninková adherence, snížená koordinace, redukce klidových glykogenových zásob, potlačená svalová proteosyntéza a pokles svalové síly (Mountjoy et al., 2014). Uvedené konsensuální vyjádření IOC $\mathrm{z}$ roku 2014 přehledně popisuje diagnostická kritéria RED-S, doporučené postupy v prevenci a nápravě RED-S.

\section{Endogenní sacharidová dostupnost (SD)}

V doporučeních pro př́jem sacharidů (S) ve sportu se termín sacharidová dostupnost (SD, carbohydrate availibility) do roku 2000 neobjevuje, nanejvýš okrajově (Burke, Cox, Cummings, \& Desbrow, 2001), avšak po roce 2010 zcela nahrazuje veškerou předchozí terminologii vyjadřující se k potřebám S ve sportu (Burke, Hawley, Wong, \& Jeukendrup, 2011). Termín SD odráží podmínky disponibilních zdrojů S (endogenních a exogenních) pro dané zatížení. Výživou (s/bez S) anebo tréninkem o různém objemu a intenzitě je možné SD dramaticky měnit.

Zvýšený př́ijem S za účelem superkompenzace svalového a jaterního glykogenu několik dnů před vrcholným závodním vytrvalostním zatížením patří mezi elementární výživové strategie vytrvalostního sportovce, je př́kladem zabezpečení vysoké endogenní SD a je velmi dobře zdokumentován (Bergström, Hermansen, Hultman, \& Saltin, 1967)the glycogen content after a fat \pm protein (P. Současná praxe přijímaných S napřr. u elitních etiopských vytrvalostních běžců $(9,7 \pm 0,9 \mathrm{~g} / \mathrm{kg})$ odráží jejich reálnou potřebu a je v souladu s aktuálními doporučeními (Beis et al., 2011). Přesto se od plošně uplatňovaného modelu vysokosacharidových diet nebo severského modelu sacharidové superkompenzační diety opouští. Burke et al. (2011) ve svých posledních doporučeních pro př́jem S na základě průkopnické práce autorů Bussau, Fairchild, Rao, Steele, \& Fournier, (2002) shrnuje, že superkompenzaci glykogenu, a tedy vysokou endogenní SD, je u jedinců konzumujících habituálně $<6-8 \mathrm{~g} \mathrm{~S} / \mathrm{kg}$ možné dosáhnout i zvýšeným př́íjmem $\mathrm{S}(10 \mathrm{~g} / \mathrm{kg})$ pouhých 24-36 hodin před plánovaným závodem.

\section{Revize doporučení pro př́ijem $\mathrm{S}$ během zatížení}

Př́ijem S v průběhu déletrvajícího zatížení (> 60-90 min) v množství 30-60 g/h zvyšuje výkon (Cermak \& van Loon, 2013) a zvýšené exogenní oxidaci (Cox et al., 2010). Jeukendrup \& Jentjens (2000) jako první shrnují, že příčiny limitující zátěžovou oxidaci S je třeba hledat v intestinální absorpci S. Resorpční kapacita glukózy je $1 \mathrm{~g} / \mathrm{min}$. Intestinální resorpční přenašeč glukózy SGLT13 je za těchto podmínek saturován. U vytrvalostního zatížení je proto tradičně doporučován př́jem nepresahující $60 \mathrm{~g} \mathrm{~S} / \mathrm{h}$. Na základě pozdějších experimentů sledujících exogenní oxidaci $\mathrm{S}$ během zátěže se ukázalo, že díky kombinovanému př́ijmu tzv. multi transportable carbohydrates jsou efektivně využity i další resorpční přenašeče (pro fruktózu specifický GLUT533). Kombinovaným

\footnotetext{
3 Monosacharidové bílkovinné přenašeče exprimované na luminální membráně enterocytů
} 
př́ijmem glukózy a fruktózy v poměru $2: 1$ je možné zvýšit exogenní oxidaci $\mathrm{S}$ až na $1,5-1,7 \mathrm{~g} /$ min (Jentjens, Achten, \& Jeukendrup, 2004). Na základě těchto zjištění byla revidována doporučení pro př́ijem $\mathrm{S}$ během zatížení na $60-90 \mathrm{~g} / \mathrm{h}$ s uplatněním u kontinuálních zatížení s délkou trvání $>2,5$ h. V oficiálních doporučeních se však výsledky z experimentů objevují až později. Např. ještě v r. 2009 tuto změnu ACSM neuváděla. V současnosti je tato revize ACSM a IOC plně akceptována, publikována $\mathrm{v}$ učebnicích sportovní výživy (Maughan, 2014) a v praxi uplatňovaná rovněž vrcholovými sportovci (Carlsohn, Nippe, Heydenreich, \& Mayer, 2012; $100 \mathrm{~km}$ cycling, $30 \mathrm{~km}$ running per wk Kumstát, Rybárová, Thomas, \& Novotný, 2015).

Př́ijem $\mathrm{S}$ u déletrvající zátěže by měl být $\mathrm{z}$ důvodu zabezpečení vysoké míry exogenní oxidace zahájen již během prvních 15-20 minut po zahájení výkonu. Přestože v tomto čase nikdo ze závodníků netrpí nedostatkem energie, můžeme v praxi běžně pozorovat první občerstvování u elitních sportovců v čase 17, resp. 13 minut (Vasův běh, 2016; 50 km na MS v klasickém lyžování, 2015) po startu (vlastní pozorování).

Z důvodu dostatečných energetických rezerv není u zatížení < 45-60 minut objektivní důvod exogenní energii třeba dodávat. Carter, Jeukendrup, \& Jones (2004) jako první prokázali, že ergogenní uplatnění S existuje i u zatížení kratších 60 minut, přestože podané S nemají žádný metabolický efekt. Navazující výzkumy v poslední dekádě odhalily přímé působení S na centrální nervovou soustavu centrální efekt. Tzv. mouth-rinse (výplach úst) představuje strategii zvyšující výkon prostřednictvím krátkého, intenzivního kontaktu S s dutinou ústní bez nutnosti jejich faktické konzumace (Pottier, Bouckaert, Gilis, Roels, \& Derave, 2010). Naprostou konzistenci v závěrech jednotlivých experimentů potvrzuje nedávná práce Devenney, Collins, \& Shortall (2016), kteří porovnávali mouth rinse $6 \%$, resp. $16 \%$ roztokem maltodextrinu s placebem u $\sim 60$ min cyklistického zatížení a potvrdili jeho ergogenní roli. Ergogenní dopad na výkon člověka není dosud přesně objasněn, ale studie založené na magnetické rezonanci naznačují souvislost mezi kontaktem S s receptory lokalizovanými v dutině ústní a aktivizací mozkových center zodpovědných za motoriku člověka (Chambers, Bridge, \& Jones, 2009). Velmi přesvědčivá a konsistentní data experimentálních prací z let 2005-2015 odhalující význam pro sportovce jsou shrnuta v mnoha studiích (Burke \& Maughan, 2015) a vedou oprávněně k zařazení do aktuálních doporučení ACSM a IOC pro prřijem S v průběhu zatížení.

\section{Záměrná manipulace s exogenní a endogenní SD}

Praktiky mnoha sportovců manipulujících SD zahrnují chronicky nízké množství S v dietě (Kavouras, Troup, \& Berning, 2004) vícefázový trénink (Cochran et al., 2015), ranní trénink po nočním lačnění (Van Proeyen, Szlufcik, Nielens, Ramaekers, \& Hespel, 2011), dlouhý trénink bez adekvátní dodávky $\mathrm{S}$ anebo absenci př́imu $\mathrm{S}$ v období po skončení zatížení ovlivňující hladiny glykogenu (Baar \& McGee, 2008).

Tyto praktiky redukující tréninkovou SD (např. redukované hladiny glykogenu) však nevedou ke snížení výkonnosti. Vedle reálného uplatňování mezi sportovci existují stále silnější odborné důkazy podporující řízenou integraci tréninkových jednotek v podmínkách nízké SD do tréninku (Close et al., 2016).

Postupy manipulující SD nejsou sportovci ani trenéry koordinované a jsou spíše důsledkem:

a) (ne)znalosti elementárních poznatků (např. sportovci si neuvědomují ergogenní význam $\mathbf{S}$, proto je nekonzumují);

b) (ne)schopnosti adekvátně kompenzovat energetický výdej (např. důsledek extrémního vrcholového zatížení);

c) (ne)možnosti dodržovat doporučené sportovně-výživové postupy (napřr. absence podmínek pro doplnění energie v období časné regenerace). 
Novou otázkou tedy není, zda v naznačených praktikách snižujicích sacharidovou dostupnost pokračovat, ale jak tyto praktiky na základě současných poznatků správně zařadit do stávajicího tréninku.

Neřízený a strategicky neplánovaný trénink v podmínkách redukovaných glykogenových rezerv anebo omezeného př́ijmu S má svá negativa. Je realizován na úkor absolutní intenzity tréninku, ovlivňuje rychlost regenerace, umocňuje zatížením vyvolanou sníženou obranyschopnost organizmu atd. Přes tato rizika přehledové práce uvádí, že trénink při snížené SD vede k rozsáhlým adaptačním změnám, jejichž projevy mohou vysvětlovat vysokou výkonnost sportovců (Burke, 2010). Snížená SD se ukazuje být silným modulujícím faktorem zatížením indukované akutní reakce ovlivňující buněčnou signalizaci a expresi genů, které regulují adaptační odpověd' na vytrvalostní trénink (např. aktivitu oxidativních enzymů a intramuskulární oxidaci tuků) (Hawley \& Burke, 2010).

V rozporu s obecně známými efekty vysoké SD, podporující soutěžní výkon a tréninkovou kapacitu sportovce, byla nově formulována tréninková strategie záměrně manipulující SD (Drust \& Morton, 2009) ve svém sdělení záměrnou manipulaci s glykogenovými zásobami pouze naznačují s tím, že jde o otevřenou výzkumnou oblast nemající odborné opodstatnění. Stěžejní práce v oblasti cílené manipulace s glykogenovými zásobami byla poprvé publikována až v r. 2005 (Hansen et al., 2005).

Na základě uvedeného je v posledních 5 letech citován koncept train low, compete high, založený na řízeném tréninku v podmínkách redukovaných endogenních nebo exogenních $\mathrm{S}$ zdrojů (Burke, 2010). Train low, compete high představuje nutriční strategii, ve které sportovci záměrně absolvují vybrané tréninkové jednotky s redukovanou SD za účelem podpory tréninkové adaptace. Na závod pak zabezpečí podmínky zajištující vysokou SD a podporu výkonu.

Hormetický efekt (prríznivé působení různých stresorů, napřr. pohybové aktivity) sacharidové restrikce zmiňují ve své práci Peake et al. (2015) Autoři uvádějí, že dosud neni možné posoudit, do jaké míry maji tyto praktiky přes popsané biochemické/molekulární změny dopady na výkonnost člověka.

\section{„Sleep low" strategie}

Sleep low strategie je mezi sportovci populární modifikací metody tréninku nalačno. Současné pojetí tréninku nalačno manipuluje pouze exogenní SD. V den předcházející tréninku nalačno není svalový glykogen vyčerpán, pokud netrénujeme nebo doplňujeme S po tréninkové jednotce v množství odpovídajícímu potřebám. Sleep low strategie kombinuje večerní intenzivní trénink s následnou záměrnou absencí př́ijmu $\mathrm{S}$ až do první ranní/dopolední tréninkové jednotky za účelem vyčerpání a nedoplnění hladin glykogenu. Sportovec jde spát „bez sacharidů“. Kombinace večerního (bez následné regenerace glykogenu) a ranního tréninku nalačno snižuje endogenní i exogenní SD a patří mezi novinky ve světě sportovní výživy. Tento koncept spadající do train-low strategie prritahuje odbornou pozornost a první výsledky pilotních metodologicky precizně propracovaných prací jsou více než slibné (Lane et al., 2015; Marquet et al., 2016).

U trénovaných jedinců a intenzivního zatížení zůstávají S dominantním energetickým substrátem. Dostupnost $\mathrm{S}$ je zcela limitující pro závodní vytrvalostní výkon. Změna dostupnosti jiných substrátů (např. u vysokotukové diety) může sice dramaticky měnit charakter jejich využití (napřs. ve prospěch zvýšené utilizace volných mastných kyselin), ale nezvyšuje výkon ve srovnání se zatížením s vysokou SD (Hawley \& Leckey, 2015).

\section{ZÁVĚR}

Sportovní výživa je progresivně se rozvíjející vědní obor. Výživové strategie sportovce zaměřené na zabezpečení energetických substrátů a dalších ergogenních prostředků podporujících dostupnost energie, oddalujících rozvoj únavy anebo zvyšujících závodní výkon jsou založeny na rozsáhlých 
literaturou podpořených důkazech. Analýza současných doporučení Americké společnosti sportovní medicíny, Mezinárodního olympijského výboru a dalších souborných prací publikovaných po roce 2010 ukázala, že tato doporučení se dynamicky mění, inovují a revidují.

Snaha o dosažení ideální tělesné hmotnosti energetickou restrikcí nebo zvýšením tréninkového energetického výdeje může vyústit v relativni energetickou nedostatečnost ve sportu, která komplexně ovlivňuje zdravotní i výkonové parametry sportovce. Je pravděpodobné, že termín relativní energetická nedostatečnost ve sportu bude v budoucnu sloužit jako preventivní nástroj hodnocení energetických potřeb sportujících mužů i žen a nahradí úzce zaměřenou ženskou atletickou triádu. Klíčovým kritériem etiopatogeneze relativní energetické nedostatečnosti ve sportu je nízká energetická dostupnost sportovce ( $\leq 30 \mathrm{kcal} / \mathrm{kg} /$ beztukové tělesné hmotnosti/den). Nízká energetická dostupnost vyjadřuje energetický př́jem nedostatečně pokrývající funkční potřeby organizmu poté, co je odečten tréninkový energetický výdej.

V př́ípadě S se ukazují být změny nekonečné. Řadu let se neměnilo tradiční doporučované dávkování 30-60 g S/h. Výkon u intenzivního vytrvalostního zatížení > 2,5-3 hod. ale vyžaduje př́ijem S v množství vyšším, a to $60-90 \mathrm{~g} / \mathrm{h}$ v průběhu celého trvání zatížení. Limitujícím faktorem uvedeného množství je intestinální absorpce tzv. multi transportable carbohydrates. Kompletní oxidaci uvedeného množství S zajistíme nejlépe kombinovaným př́ijmem glukózy a fruktózy poměru $2: 1$. Tímto př́stupem pro závod zabezpečíme vysokou exogenní sacharidovou dostupnost.

U zatížení $\sim 1$ h není za podmínek dostatečných energetických zásob nutné energii dodávat. V prŕípadě 45-75 min. intenzivního souvislého zatížení, popř. intermitentního zatížení (intervalový trénink) s vysokým energetickým výdejem, je prokázáno zvýšení výkonnosti po přísunu velmi malého množství S. V posledních letech se navíc potvrzuje, že rovněž bez faktického přísunu (konzumace) $\mathrm{S}$ a po pouhém kontaktu $\mathrm{S}$ (ne jiných makroživin) s dutinou ústní dochází ke zlepšení pracovní kapacity.

Model train low, compete high dokumentuje, že záměrná manipulace se sacharidovou dostupností a zejména trénink v podmínkách nízké sacharidové dostupnosti je silným adaptačním stimulem. Vzniklá modifikace populárního tréninku nalačno, tzv. sleep low strategie (poprvé popisovaná roku 2015), je př́slibem zajímavých výzkumů, které mohou sportovcům nabídnout konkrétní tréninkové modely optimalizující tréninkovou odpověd’. Strategické a periodizované změny v př́ijmu sacharidů měnící endogenní nebo exogenní sacharidovou dostupnost zesilují tréninkem indukované adaptace kosterního svalstva, jako např. exprese genů účastnících se regulace adaptačních procesů, zvyšují aktivitu oxidativních enzymů a intramuskulární oxidaci tuků. Rada současných experimentů a intervenčních studií přináší přsesvědčivé důkazy pro uvedené změny.

\section{Literatura}

American College of Sports Medicine, American Dietetic Association, \& Dietitians of Canada. (2000). Joint Position Statement: nutrition and athletic performance. American College of Sports Medicine, American Dietetic Association, and Dietitians of Canada. Medicine and Science in Sports and Exercise, 32(12), 2130-2145.

Baar, K., \& McGee, S. (2008). Optimizing training adaptations by manipulating glycogen. European Journal of Sport Science, $8(2), 97-106$.

Barrack, M. T., Ackerman, K. E., \& Gibbs, J. C. (2013). Update on the female athlete triad. Current Reviews in Musculoskeletal Medicine, 6(2), 195-204.

Beis, L. Y., Willkomm, L., Ross, R., Bekele, Z., Wolde, B., Fudge, B., \& Pitsiladis, Y. P. (2011). Food and macronutrient intake of elite Ethiopian distance runners. Journal of the International Society of Sports Nutrition, 8, 7.

Bergström, J., Hermansen, L., Hultman, E., \& Saltin, B. (1967). Diet, Muscle Glycogen and Physical Performance. Acta Physiologica Scandinavica, 71(2-3), 140-150. 
Broad, E. M., \& Cox, G. R. (2008). What is the optimal composition of an athlete's diet? European Journal of Sport Science, $8(2), 57-65$

Burke, L. M. (2010). Fueling strategies to optimize performance: training high or training low? Scandinavian journal of medicine \& science in sports, 20 Suppl 2, 48-58.

Burke, L. M., Cox, G. R., Cummings, N. K., \& Desbrow, B. (2001). Guidelines for Daily Carbohydrate Intake: Do Athletes Achieve Them? Sports Medicine, 31(4), 267-299.

Burke, L. M., Hawley, J. A., Wong, S. H. S., \& Jeukendrup, A. E. (2011). Carbohydrates for training and competition. Journal of Sports Sciences, 29(sup1), S17-S27.

Burke, L. M., \& Maughan, R. J. (2015). The Governor has a sweet tooth - Mouth sensing of nutrients to enhance sports performance. European Journal of Sport Science, 15(1), 29-40.

Bussau, V. A., Fairchild, T. J., Rao, A., Steele, P., \& Fournier, P. A. (2002). Carbohydrate loading in human muscle: an improved 1 day protocol. European Journal of Applied Physiology, 87(3), 290-295.

Carlsohn, A., Nippe, S., Heydenreich, J., \& Mayer, F. (2012). Carbohydrate intake and food sources of junior triathletes during a moderate and an intensive training period. International Journal of Sport Nutrition and Exercise Metabolism, 22(6), 438-443.

Carter, J. M., Jeukendrup, A. E., \& Jones, D. A. (2004). The effect of carbohydrate mouth rinse on 1-h cycle time trial performance. Medicine and Science in Sports and Exercise, 36(12), 2107-2111.

Cermak, N. M., \& van Loon, L. J. C. (2013). The use of carbohydrates during exercise as an ergogenic aid. Sports Medicine, 43(11), 1139-1155.

Close, G. I., Hamilton, D. I., Philp, A., Burke, L. m., \& Morton, J. p. (2016). New strategies in sport nutrition to increase exercise performance. Free Radical Biology and Medicine.

Cochran, A. J. R., Myslik, F., Maclnnis, M. J., Percival, M. E., Bishop, D., Tarnopolsky, M. A., \& Gibala, M. J. (2015). Manipulating Carbohydrate Availability Between Twice-Daily Sessions of High-Intensity Interval Training Over 2 Weeks Improves Time-Trial Performance. International Journal of Sport Nutrition \& Exercise Metabolism, 25(5), 463-470. 63

Cox, G. R., Clark, S. A., Cox, A. J., Halson, S. L., Hargreaves, M., Hawley, J. A., ... Burke, L. M. (2010). Daily training with high carbohydrate availability increases exogenous carbohydrate oxidation during endurance cycling. Journal of Applied Physiology, 109(1), 126-134.

Devenney, S., Collins, K., \& Shortall, M. (2016). Effects of various concentrations of carbohydrate mouth rinse on cycling performance in a fed state. European Journal of Sport Science, 0(0), 1-6.

Drust, B., \& Morton, J. P. (2009). Promoting Endurance Training Adaptations with Nutritional Interventions: The Potential Benefits of "Low Carbohydrate" Training. Kinesiology, 41(1), 19-24.

Hansen, A. K., Fischer, C. P., Plomgaard, P., Andersen, J. L., Saltin, B., \& Pedersen, B. K. (2005). Skeletal muscle adaptation: training twice every second day vs. training once daily. Journal of Applied Physiology (Bethesda, Md.: 1985), 98(1), 93-99.

Hawley, J. A., \& Burke, L. M. (2010). Carbohydrate Availability and Training Adaptation: Effects on Cell Metabolism. Exercise and Sport Sciences Reviews, 38(4), 152-160.

Hawley, J. A., \& Leckey, J. J. (2015). Carbohydrate Dependence During Prolonged, Intense Endurance Exercise. Sports Medicine, 45(1), 5-12.

Chambers, E. S., Bridge, M. W., \& Jones, D. A. (2009). Carbohydrate sensing in the human mouth: effects on exercise performance and brain activity. The Journal of Physiology, 587(Pt 8), 1779-1794.

IOC consensus statement on sports nutrition 2010. (2011). Journal of Sports Sciences, 29(sup1), S3-S4.

Jentjens, R. L. P. G., Achten, J., \& Jeukendrup, A. E. (2004). High oxidation rates from combined carbohydrates ingested during exercise. Medicine and Science in Sports and Exercise, 36(9), 1551-1558.

Jeukendrup, A. E. (2004). Carbohydrate intake during exercise and performance. Nutrition, 20(7-8), 669-677.

Jeukendrup, A. E., \& Jentjens, R. (2000). Oxidation of carbohydrate feedings during prolonged exercise: current thoughts, guidelines and directions for future research. Sports Medicine, 29(6), 407-424.

Kavouras, S. A., Troup, J. P., \& Berning, J. R. (2004). The influence of low versus high carbohydrate diet on a 45-min strenuous cycling exercise. International Journal of Sport Nutrition and Exercise Metabolism, 14(1), 62-72.

Kumstát, M., Rybárová, S., Thomas, A., \& Novotný, J. (2015). Case Study: Competition Nutrition Intakes during the Open Water Swimming Grand Prix Races in Elite Female Swimmer. International Journal of Sport Nutrition and Exercise Metabolism.

Lane, S. C., Camera, D. M., Lassiter, D. G., Areta, J. L., Bird, S. R., Yeo, W. K., ... Hawley, J. A. (2015). Effects of sleeping with reduced carbohydrate availability on acute training responses. Journal of Applied Physiology (Bethesda, Md.: 1985), 119(6), 643-655.

Loucks, A. B., Kiens, B., \& Wright, H. H. (2011). Energy availability in athletes. Journal of Sports Sciences, 29(sup1), S7-S15.

Marquet, L.-A., Brisswalter, J., Louis, J., Tiollier, E., Burke, L. M., Hawley, J. A., \& Hausswirth, C. (2016). Enhanced Endurance Performance by Periodization of CHO Intake: "Sleep Low” Strategy. Medicine and Science in Sports and Exercise.

Maughan, R. J. (2014). The Encyclopaedia of Sports Medicine: An IOC Medical Commission Publication, Sports Nutrition. John Wiley \& Sons. 
Mountjoy, M., Sundgot-Borgen, J., Burke, L., Carter, S., Constantini, N., Lebrun, C., ... Ljungqvist, A. (2014). The IOC consensus statement: beyond the Female Athlete Triad-Relative Energy Deficiency in Sport (RED-S). British Journal of Sports Medicine, 48(7), 491-497.

Nattiv, A., Loucks, A. B., Manore, M. M., Sanborn, C. F., Sundgot-Borgen, J., Warren, M. P., \& American College of Sports Medicine. (2007). American College of Sports Medicine position stand. The female athlete triad. Medicine and Science in Sports and Exercise, 39(10), 1867-1882.

Peake, J. M., Markworth, J. F., Nosaka, K., Raastad, T., Wadley, G. D., \& Coffey, V. G. (2015). Modulating exercise-induced hormesis: Does less equal more? Journal of Applied Physiology, 119(3), 172-189.

Pottier, A., Bouckaert, J., Gilis, W., Roels, T., \& Derave, W. (2010). Mouth rinse but not ingestion of a carbohydrate solution improves 1-h cycle time trial performance. Scandinavian Journal of Medicine \& Science in Sports, 20(1), 105-111.

Sherman, W. M. (1995). Metabolism of sugars and physical performance. The American Journal Of Clinical Nutrition, 62(1 Suppl), 228S-241S.

Thomas, D. T., Erdman, K. A., \& Burke, L. M. (2016). American College of Sports Medicine Joint Position Statement. Nutrition and Athletic Performance. Medicine and Science in Sports and Exercise, 48(3), 543-568

Van Proeyen, K., Szlufcik, K., Nielens, H., Ramaekers, M., \& Hespel, P. (2011). Beneficial metabolic adaptations due to endurance exercise training in the fasted state. Journal of Applied Physiology, 110(1), 236-245.

\section{Corresponding author}

Mgr. Michal Kumstát, Ph.D.,

Fakulta sportovních studií, Masarykova univerzita, Brno, Česká republika

kumstat@fsps.muni.cz 